\title{
Studi Pustaka Sistem Pemantauan Jaringan Distribusi Air Publik berbasis Internet of Things (IoT)
}

\author{
I Putu Arya Dharmaadi, Dewa Made Sri Arsa \\ Program Studi Teknologi Informasi, Fakultas Teknik, Universitas Udayana \\ e-mail: aryadharmaadi@unud.ac.id, dewamsa@unud.ac.id
}

\begin{abstract}
Abstrak
Jaringan pipa air suatu daerah yang dikelola oleh PDAM (Perusahaan Daerah Air Minum) berfungsi untuk mendistribusikan kebutuhan air bersih bagi masyarakat. Namun, sering kali proses distribusi air bersih ini tersendat yang disebabkan oleh beberapa faktor, seperti pasokan air dari hulu yang menipis, sumber air kotor dan berlumpur, atau jaringan pipa yang bermasalah. Dengan demikian, pada penelitian ini akan dilakukan peninjauan dan pembahasan terhadap solusi-solusi berbasis Internet of Things (IOT) yang dirancang oleh para peneliti terkait permasalahan pada sektor jaringan distribusi air publik. Peninjauan dan pembahasan ini bertujuan untuk mengetahui masalah apa sering muncul dan sampai sejauh mana solusi yang dirancang yang bisa dimanfaatkan oleh PDAM. Studi pustaka dilakukan dengan mempelajari artikel-artikel terkait yang dipublikasikan pada jurnal internasional terindeks Scopus yang terbit selama 5 tahun terakhir. Dari penelitian berbasis literature review ini, didapatkan permasalahan yang masih terbuka yang belum diselesaikan yang bisa dirumuskan solusinya lebih lanjut. Salah satunya adalah permasalahan pelanggan yang tidak mendapatkan informasi terkini terkait kondisi jaringan air publik.
\end{abstract}

Kata kunci: studi, pustaka, pemantauan, distribusi, air, loT

\section{Abstract}

The pipeline network in such area managed by PDAM (Regional Water Supply Company) functions to distribute clean water needs to the community. However, often the process of clean water distribution is stalled due to several factors, such as a depleted upstream water supply, dirty and muddy water sources, or problematic pipelines. Thus, in this research, we will review and discuss about Internet of Things (IOT) based solutions that have been conducted by researchers related to problems in the public water distribution sector. This review and discussion aims to find out what problems often arise and to what extent solutions are designed that can be utilized by PDAM. The literature review is carried out by studying related articles published in Scopus indexed international journals published over the past 5 years. From this literature-based research, we found that there are still open problems that have not been resolved that can be formulated further. One of them is the problem of customers who do not get the latest information related to the condition of public water distribution.

Keywords : literature, review, monitoring, distribution, water, IoT

\section{Pendahuluan}

Air bersih yang bersumber dari PDAM (Perusahaan Daerah Air Minum) merupakan kebutuhan pokok masyarakat yang tinggal di kota-kota besar. Hampir setiap kota memiliki PDAM yang berfungsi untuk mendistribusikan kebutuhan air bersih dan mengalami peningkatan jumlah pengguna. Sebagai contoh, pada kabupaten Badung yang merupakan daerah pariwisata terbesar, memiliki 73.281 pelanggan dengan cakupan pelayanan sebesar $71,53 \%$ dan kapasitas produksi sebesar $45.265 .972 \mathrm{~m}^{3}$ [1]. Mengingat kebutuhan pada air bersih terus meningkat karena bertambahnya jumlah penduduk, PDAM dituntut terus bisa memberikan pelayanan terbaik dalam mendistribusikan air bersih. Dalam situasi normal, debit air PDAM mampu memenuhi kebutuhan sehari-hari pelanggannya. Namun, ada kalanya aliran air PDAM mengecil dan bahkan mati atau tidak mengalir sama sekali. Hal ini disebabkan oleh pasokan air dari hulu (sungai, waduk, atau danau) yang sedang menipis atau karena adanya gangguan pada jaringan pipa PDAM [2]. Ketidaklancaran yang sering kali terjadi ini menyebabkan aktivitas 
rutin masyarakat, seperti mandi atau memasak, menjadi terhenti mengingat air bersih merupakan kebutuhan pokok [3]. Melihat kondisi tersebut, dapat dipastikan infrastruktur dari sistem pengelolaan air bernilai sangat tinggi.

Infrastruktur sistem pengelolaan dan distribusi air publik berperan penting karena menjadi tulang punggung sistem penyediaan air bersih kepada masyarakat. Infrastruktur ini terdiri dari beberapa komponen utama, yaitu: 1) sumber air sebagai bahan baku utama yang menyediakan air bersih, 2) sistem produksi sebagai instalasi pengolahan air baku menjadi air bersih siap pakai, 3) sistem transmisi sebagai tempat penampungan, dan 4) sistem distribusi sebagai sistem penyaluran air bersih dari penampungan menuju pelanggan [4]. Keberadaan tempat penampungan (reservoir) akan menjamin persediaan air bersih ketika sumber air mengalami kendala dan menyeimbangkan tekanan air.

Untuk menjaga kondisi infrastruktur air agar selalu dalam kondisi yang prima, pemerintah daerah mengalokasikan dana untuk merawat sistem pengelolaan air. Untuk mencegah terjadinya dampak yang luas bagi masyarakat, perlu dilakukan monitoring secara kontinyu pada perangkat sistem pengelolaan air hingga pendistribusiannya. Teknologi informasi seperti Internet of Things (IoT) dapat dijadikan sebagai salah satu solusi dalam monitoring pengelolaan air, khususnya PDAM, serta mengatasi permasalahan terkait menurunnya debit air bersih yang disediakan oleh PDAM. Teknologi loT merupakan inovasi baru untuk menggantikan sistem pemantauan konvensional yang memiliki banyak keterbatasan [5]. Dengan menerapkan IoT di suatu perusahaan, petugas bisa berkomunikasi dengan semua komponen infrastruktur perusahaan melalui pemantauan jarak jauh terus menerus [6]. Dampaknya, petugas bisa cepat dan tanggap dalam merespon suatu masalah terkait infrastruktur sebelum masalah tersebut membesar dan menghambat pelayanan kepada pelanggan.

Berdasarkan uraian di atas, pada penelitian ini, akan dilakukan peninjauan dan pembahasan terhadap solusi-solusi berbasis loT yang telah dirancang oleh para peneliti terkait permasalahan pada sektor jaringan distribusi air publik. Peninjauan dan pembahasan ini bertujuan untuk mengetahui sampai sejauh mana solusi yang dirancang dan masalah apa yang masih belum terselesaikan. Pada akhirnya, PDAM bisa mengetahui dan mempertimbangkan untuk menerapkan prototipe sistem apa yang sedang dikembangkan belakangan ini. Bagi peneliti lain, riset ini bisa membantu untuk memahami permasalahan apa yang masih terbuka yang belum diselesaikan yang bisa dirumuskan solusinya lebih lanjut pada penelitian berikutnya.

\section{Metodologi Penelitian}

Metodologi penelitian merupakan langkah-langkah yang dikerjakan untuk menyelesaikan penelitian ini. Pada penelitian berbasis literature review ini, akan dilakukan 3 tahapan, yaitu pengumpulan artikel jurnal, identifikasi masalah dan usulan sistem, dan pembahasan open problem dan tantangan penerapan loT. Ketiga tahapan tersebut akan dijelaskan sebagai berikut.

\subsection{Pengumpulan Artikel Jurnal}

Tahapan ini merupakan langkah untuk mendapatkan artikel-artikel ilmiah yang akan diidentifikasi. Artikel ilmiah didapatkan dengan memanfaatkan layanan pencarian online pada 3 sistem informasi terkenal dalam mengindeks jurnal bereputasi Scopus, yaitu ACM Digital Library, IEEE Explorer, dan Science Direct. Artikel utama yang dipilih adalah artikel yang dipublikasikan dalam bentuk jurnal (bukan prosiding) yang terbit dalam rentang waktu 5 tahun terakhir. Tujuannya adalah untuk mendapatkan artikel ilmiah yang mendalam dan berkualitas serta masih relevan dengan kondisi saat ini. Namun, beberapa artikel yang terbit dalam prosiding yang pembahasannya cukup mendalam akan digunakan sebagai artikel pelengkap. Kata kunci atau keyword yang digunakan dalam pencarian adalah "public water monitoring iot". Namun, tidak semua artikel yang muncul dari hasil pencarian otomatis dimasukkan dalam daftar artikel. Bagian abstrak dari artikel-artikel hasil pencarian akan diperiksa untuk mengetahui topik inti yang akan dibahas. Akan dicari artikel yang khusus membahas mengenai perancangan sistem untuk jaringan distribusi air bersih. Hanya artikel-artikel yang memenuhi kondisi tersebut yang akan dimasukan ke dalam daftar artikel dan dianalisa lebih lanjut di tahap berikutnya. 


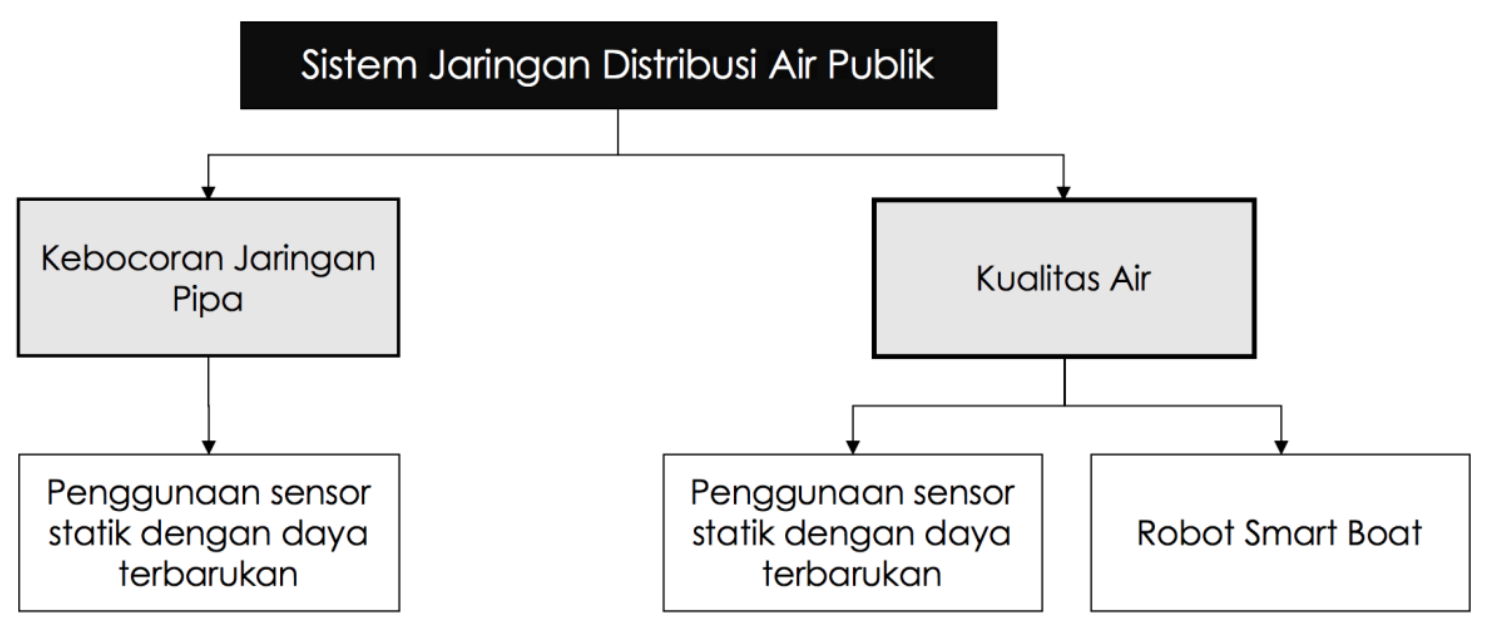

Gambar 1. Gambaran masalah dan teknologi secara umum pada sistem jaringan distribusi air

\subsection{Identifikasi Masalah dan Usulan Sistem}

Tahapan ini merupakan langkah untuk mengidentifikasi artikel-artikel yang telah terpilih sehingga bisa dilakukan pemetaan terhadap rumusan masalah yang diangkat dan desain sistem yang diusulkan. Proses identifikasi artikel meliputi pendalaman bagian tujuan penelitian, rumusan masalah yang diangkat, keunikan desain sistem atau solusi yang ditawarkan jika dibandingkan dengan penelitian lainnya. Hasil-hasil pendalaman dicatat untuk kemudian dikelompokkan berdasarkan kemiripan permasalahan yang berusaha dipecahkan dan usulan solusi yang diberikan. Dari hasil pengelompokan, akan dibentuk menjadi sebuah gambaran penelitian antara masalah dan teknologi secara umum pada sistem jaringa distribusi air publik. Gambaran ini bertujuan untuk mempermudah pembaca dalam memahami sudah sampai sejauh mana solusi yang dirancang.

\subsection{Pembahasan Open Problem dan Tantangan dalam Penerapan loT}

Tahapan ini merupakan langkah terakhir dari kegiatan penelitian literature review. Tahapan ini akan menganalisa desain solusi yang diusulkan oleh para peneliti untuk mengetahui masalah apa yang masih tersisa (open problem) dari penerapan desain tersebut. Open problem perlu dianalisa karena perancangan teknologi tidak selalu sempurna dan masih ada tantangan yang perlu diselesaikan. Peneliti-peneliti lainnya bisa memanfaatkan open problem ini sebagai celah untuk mengembangkan kembali atau bahkan menyempurnakan prototipe sistem yang sudah dirancang oleh peneliti terdahulu.

\section{Hasil Identifikasi Masalah}

Dari artikel-artikel yang berhasil dikumpulkan, didapatkan beberapa masalah sejenis sehingga bisa dikelompokkan menjadi 2 kelompok, yaitu masalah pada sisi jaringan pipa, dan masalah pada kualitas air. Untuk lebih jelasnya dapat dilihat gambaran penelitian pada Gambar 1.

Sistem perpipaan air publik memegang peranan yang sangat vital karena bertugas mendistribusikan air bersih dari sumber mata air dan bak penampungan air (reservoir) ke kawasan industri, komersial, dan perumahan [7]. Sistem tersebut terdiri dari sejumlah reservoir air dan pipa jalur utama yang mengalir, dibagi lagi menjadi sub-sub induk, dan jalur cabang kecil yang mengalirkan air ke rumah-rumah pelanggan. Akan tetapi, sebagian besar sistem ini dalam kondisi yang buruk dan sering terjadi kebocoran air sehingga dibutuhkan sistem yang mampu mengawasi kebocoran air dan kontaminasi meskipun dengan tantangan berupa pipa yang tertanam jauh di bawah tanah sehingga sulit untuk dijangkau oleh teknisi dan jauh dari jangkauan jaringan listrik [8]. Selain masalah mendeteksi lokasi kebocoran, masalah kondisi kualitas air yang dialirkan juga menjadi fokus di beberapa penelitian seperti yang dikerjakan oleh [9]. Masalah ini cukup kompleks karena penempatan beberapa sensor pada jaringan pipa terkendala daya baterai yang terbatas sehingga perlu diisi ulang secara rutin. 
Tabel 1. Sensor-sensor yang pernah digunakan unntuk mendeteksi kebocoran pada pipa

\begin{tabular}{ccll}
\hline No. & Penelitian & Tujuan Pembuatan Sistem & \multicolumn{1}{c}{ Sensor } \\
\hline 1 & Oh dkk. [15] & $\begin{array}{l}\text { Deteksi kebocoran pada pipa } \\
\text { pada power plant atau parbrik } \\
\text { manufaktur }\end{array}$ & Distributed acoustic sensor \\
\hline 2 & $\begin{array}{c}\text { Machado } \\
\text { dkk. [12] }\end{array}$ & Memantau suplai air pada pipa & $\begin{array}{l}\text { WSN dengan ZR16S08 sebagai } \\
\text { mikrokontroler, Raspberry Pi } \\
\text { sebagai CPU }\end{array}$ \\
\hline 3 & $\begin{array}{r}\text { Rabeek dkk. } \\
{[13]}\end{array}$ & Mendeteksi kebocoran air & $\begin{array}{l}\text { Hydrophone sensor + ARM micro } \\
\text { controller }\end{array}$ \\
\hline 4 & $\begin{array}{r}\text { Priya dkk. } \\
{[16]}\end{array}$ & $\begin{array}{l}\text { Deteksi pencurian air, kontrol } \\
\text { kualitas air, prediksi dan } \\
\text { lokalisasi kebocoran }\end{array}$ & $\begin{array}{l}\text { Menggunakan berbagai macam } \\
\text { sensor }\end{array}$ \\
\hline 5 & $\begin{array}{r}\text { Elleuchi dkk. } \\
{[14]}\end{array}$ & Mendeteksi kebocoran air & Sensor kelembaban \\
\hline 6 & $\begin{array}{c}\text { Ayadi dkk. } \\
{[17]}\end{array}$ & $\begin{array}{l}\text { Identifikasi dan lokalisasi } \\
\text { kerusakan pada pipa air }\end{array}$ & Sensor tekanan \\
\hline
\end{tabular}

Organisasi pengelola air bersih memanfaatkan sungai, danau, atau waduk sebagai sumber air yang akan didistribusikan kepada masyarakat. Air tersebut umumnya ditampung terlebih dahulu pada sebuah bak besar (reservoir) yang berfungsi sebagai tempat penyimpanan cadangan air ketika sumber air menipis, penyeimbang debit aliran, dan pemerataan tekanan ke semua pelanggan [10]. Permasalahan yang umumnya terjadi adalah kualitas air bersih yang tidak terjaga pada sumber air maupun pada tempat penampungan yang disebabkan oleh tumpahan minyak, limbah plastik, maupun aktivitas manusia. Untuk itu, sangat penting untuk melindungi sumber daya air dari kontaminasi dan memantau serta melacak kondisi air untuk memastikan keamanan dan kualitas sumber air [11]. Umumnya, sistem pemantauan air otomatis yang sudah ada di pasaran memiliki harga yang mahal dengan ukuran cukup besar sehingga diperlukan teknologi yang lebih murah dan mudah diaplikasikan.

\section{Sistem Pemantauan Pipa Berbasis loT}

Beberapa penelitian tentang pendeteksian kebocoran pipa telah dilakukan dengan berbagai macam jenis sensor seperti yang diperlihatkan pada Tabel 1. Secara umum, sistem yang dibangun menggunakan skema Wireless Sensor Network (WSN) seperti yang diperlihatkan pada Gambar 2. Sistem ini terdiri dari 3 komponen, yaitu sensor, base station, dan server. Namun, beberapa penelitian menggunakan central processing unit (CPU) sebagai base station. Data yang diperoleh dari beberapa sensor akan diterima oleh CPU untuk diteruskan ke server.

Penelitian [12][13][14] dikembangkan untuk mendeteksi kebocoran air pada pipa, sedangkan penelitian [15] dikembangkan untuk memantau kondisi pipa pada pabrik manufaktur atau pembangkit. Pada penelitian [16] lebih difokuskan pada pemantauan kontaminasi pada pipa untuk air minum. Dari simulasi yang dilakukan, hanya penelitian [14] yang melakukannya dengan menanam sensor di dalam tanah.

Sensor-sensor yang ditanamkan pada pipa memerlukan sumber daya agar dapat bekerja dan sumber daya tersebut perlu diperhitungkan ketahanannya dengan cara mengurangi konsumsi energy dan optimasi komunikasi pada sensor [17]. Penelitian yang dikerjakan oleh [8] merancang jaringan sensor yang dapat digunakan di jaringan air bawah tanah dengan perangkat sensor yang dipasang pada sambungan pipa atau titik-titik katup pipa dan tanpa perlu mengganti ulang baterai karena sistem hanya digerakkan oleh energi yang didapat dari pergerakan air. Aliran air akan memutar unit kipas kecil yang bisa dikonversi menjadi energi listrik dan disimpan pada baterai. Dengan penerapan sistem ini, jika terjadi kebocoran pada pipa, waktu pelaporan kepada petugas menjadi sangat singkat dan perawatan sistem lebih 


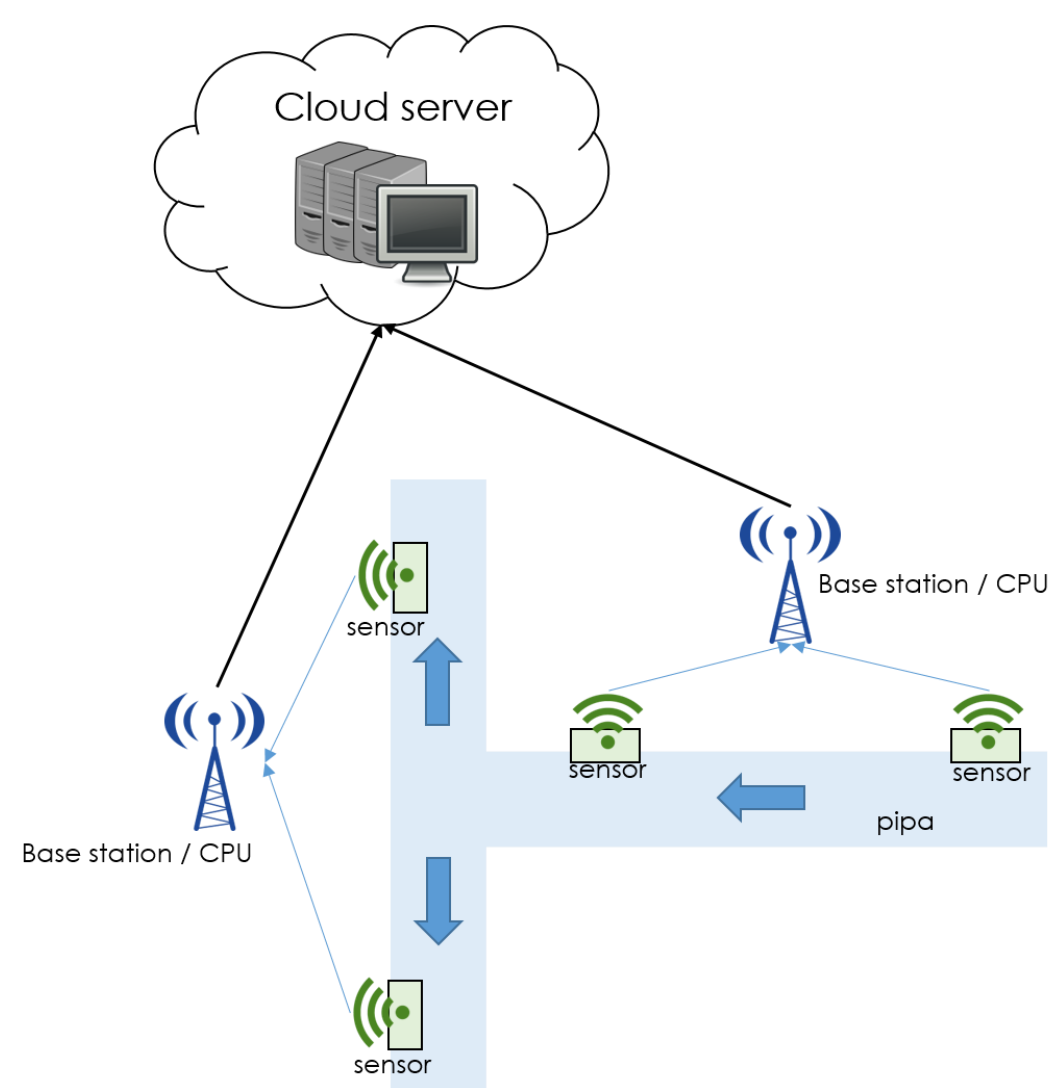

Gambar 2. Skema WSN secara umum [16]

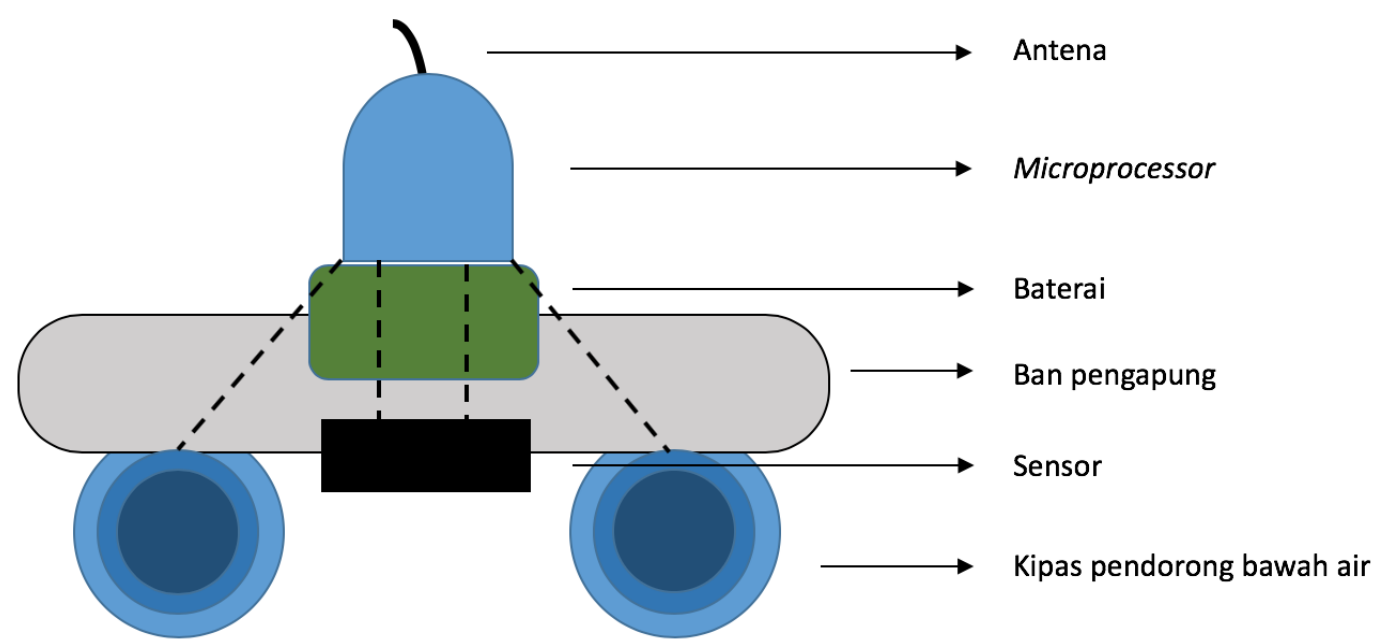

Gambar 3. Prototipe robot SmartBOAT 3 yang dirancang oleh [11]

mudah karena tidak perlu mengganti baterai sensor secara berkala. Perangkat sensor yang digunakan adalah waterflow meter dan water quality sensor.

\section{Sistem Pemantauan Kualitas Air Berbasis loT}

Penelitian terkait jaringan sensor dengan energi terbarukan juga dikerjakan oleh [9] yang merancang sistem sensor untuk memonitor kualitas air yang mampu mengisi ulang baterainya secara mandiri. Perbedaannya adalah sistem ini ditenagai oleh bioenergi terbarukan yang dihasilkan dari sel bahan bakar mikroba (MFC) yang mengumpulkan energi yang dilepaskan dari native magnesium oxidizing microorganisms (MOM) yang berlimpah di perairan alami. Perangkat sensor yang digunakan adalah TelosB mote, AtlasScientific temperature 
sensor, dan AtlasScientific $\mathrm{pH}$ sensor yang mengukur temperatur, DO, dan $\mathrm{pH}$ air. Prototipe sistem ini cocok untuk diinstalasi pada lingkungan sungai, danau, atau reservoir.

Berbeda dengan peneliti lain yang mengembangkan jaringan sensor yang bersifat statik (tidak bisa berpindah-pindah), penelitian yang dikerjakan oleh [11] merancang robot cerdas yang bisa mengapung dan menyusuri air. Robot ini dilengkapi dengan sensor air yang siap pakai untuk memperoleh data seperti $\mathrm{pH}$, tekanan, dan suhu untuk mengukur kualitas air dalam sumber daya air, seperti kolam, waduk, danau, atau reservoir. Robot tersebut dilengkapi dengan aplikasi Android sehingga pengguna dapat dengan mudah mengontrol robot melalui Bluetooth dan menampilkan data sensor dan GPS yang dihasilkan oleh platform. Robot ini memiliki ukuran $28 \times 24 \times 28 \mathrm{~cm}$ dengan bobot $3 \mathrm{~kg}$.

\section{Tantangan Penerapan loT Pada Sistem Pemantauan Distribusi Air}

Dari prototipe-prototipe sistem yang diusulkan di atas, keseluruhan prototipe masih menyimpan permasalahan yang masih belum terselesaikan. Sistem yang diusulkan oleh [8] memiliki solusi yang baik untuk mengatasi masalah isi ulang baterai, namun untuk mendeteksi titik atau lokasi kebocoran pipa masih memiliki kekurangan karena tidak mampu menjangkau keseluruhan pipa. Sistem hanya mampu memperkirakan posisi kebocoran pada area sekitar pemasangan sensor, yaitu pada titik sambungan pipa. Sementara itu, prototipe jaringan sensor yang diusulkan oleh [9] sangat menarik karena mampu memonitoring kualitas air pada suatu area permukaan secara statik dalam jangka waktu yang panjang karena dilengkapi juga dengan sistem isi ulang baterai secara otomatis. Penelitian lainnya yang diusulkan oleh [11] telah mampu menghasilkan smart robot yang menyusuri air sesuai dengan rute yang diberikan melalui aplikasi Android. Namun, akan lebih baik apabila smart robot mampu menentukan rute sendiri secara otomatis untuk bergerak memantau keseluruhan kualitas air di suatu tempat, misalnya pada waduk, danau, atau bak reservoir.

Terkait dengan sistem jaringan distribusi air publik, akan lebih bermanfaat dan transparan apabila keseluruhan prototipe sistem di atas mampu memberikan layanan berupa informasi kondisi kualitas air bersih kepada pelanggan sehingga pelanggan juga mengetahui bagaimana kondisi air yang mereka konsumsi.

\section{Kesimpulan}

Berdasarkan hasil pembahasan di atas, diketahui bahwa sistem jaringan distribusi air publik memiliki 2 masalah utama yang menjadi fokus peneliti belakangan ini, yaitu masalah kebocoran jaringan pipa dan masalah kualitas air reservoir. Permasalahan tersebut berusaha dipecahkan dengan merancang sistem sensor dengan baterai isi ulang otomatis dan robot smartboat. Dari pemaparan tersebut, ada beberapa masalah yang bisa dikerjakan pada penelitian berikutnya, antara lain masalah deteksi titik kebocoran keseluruhan pipa, masalah penentuan rute secara otomatis pada robot SmartBoat, hingga masalah layanan informasi realtime kepada pelanggan.

\section{Daftar Pustaka}

[1] "Laporan Bidang Teknik Tahun 2019 Bulan Desember PDAM Tirta Mangutama Kabupaten Badung," Badung, 2020.

[2] B. Ulum, "Kenapa Air PAM Sering Crat-crit atau Mati?," Kompasiana, Brebes, 2019.

[3] Fazri, "Ibu Rumah Tangga Sewot, Aliran Air PDAM Tak Lancar," Radar Cirebon, Cirebon, 2017.

[4] R. Susanti, "PEMETAAN PERSOALAN SISTEM PENYEDIAAN AIR BERSIH UNTUK MENINGKATKAN KUALITAS SISTEM PENYEDIAAN AIR," J. Perenc. Wil. dan Kota, vol. 21, no. 2, pp. 111-128, 2010.

[5] K. S. Adu-Manu, C. Tapparello, W. Heinzelman, F. A. Katsriku, and J. D. Abdulai, "Water quality monitoring using wireless sensor networks: Current trends and future research directions," ACM Trans. Sens. Networks, vol. 13, no. 1, 2017.

[6] M. Kranz, Building the Internet of Things: Implement New Business Models, Disrupt Competitors, Transform Your Industry. New Jersey: John Wiley \& Sons, Inc, 2016.

[7] M. Kautsar, R. R. Isnanto, and E. D. Widianto, "Sistem Monitoring Digital Penggunaan dan Kualitas Kekeruhan Air PDAM Berbasis Mikrokontroler ATMega328 Menggunakan Sensor Aliran Air dan Sensor Fotodiode," J. Teknol. dan Sist. Komput., vol. 3, no. 1, pp. 
79-86, 2015.

[8] A. Pal and K. Kant, "Water Flow Driven Sensor Networks for Leakage and Contamination Monitoring in Distribution Pipelines," ACM Transactions on Sensor Networks, vol. 15, no. 4. 2019.

[9] Q. Chen et al., "Harvest Energy from theWater: A Self-SustainedWirelessWater Quality Sensing System," ACM Trans. Embed. Comput. Syst., vol. 17, no. 1, pp. 1-24, 2017.

[10] Y. Kusumawardani and W. Astuti, "Evaluasi Pengelolaan Sistem Penyediaan Air Bersih Di PDAM Kota Madiun," Neo Tek., vol. 4, no. 1, pp. 1-10, 2018.

[11] W. Jo, Y. Hoashi, L. L. P. Aguilar, M. Postigo-Malaga, J. M. Garcia-Bravo, and B. C. Min, "A low-cost and small USV platform for water quality monitoring," HardwareX, vol. 6, 2019.

[12] M. R. Machado, T. R. Júnior, M. R. Silva, and J. B. Martins, "Smart Water Management System using the Microcontroller ZR16S08 as IoT Solution," in 2019 IEEE 10th Latin American Symposium on Circuits Systems (LASCAS), 2019, pp. 169-172.

[13] S. M. Rabeek, H. Beibei, and K. T. C. Chai, "Design of Wireless IoT Sensor Node Platform for Water Pipeline Leak Detection," in 2019 IEEE Asia-Pacific Microwave Conference (APMC), 2019, pp. 1328-1330.

[14] M. Elleuchi, R. Khelif, M. Kharrat, M. Aseeri, A. Obeid, and M. Abid, "Water Pipeline Monitoring and Leak Detection using soil moisture Sensors: IoT based solution," in 2019 16th International Multi-Conference on Systems, Signals Devices (SSD), 2019, pp. 772775.

[15] S. W. Oh, J. Bae, D. Yoon, B. Yang, G. J. Kim, and H. Soo Kim, "A study on Improvement of Resource Efficiency for loT-based Pipe Leak Detection," in 2018 International Conference on Information and Communication Technology Convergence (ICTC), 2018, pp. 1423-1425.

[16] S. K. Priya, G. Shenbagalakshmi, and T. Revathi, "IoT Based Automation of Real Time In-Pipe Contamination Detection System in Drinking Water," in 2018 International Conference on Communication and Signal Processing (ICCSP), 2018, pp. 1014-1018.

[17] A. Ayadi, O. Ghorbel, M. S. BenSalah, and M. Abid, "Spatio-temporal correlations for damages identification and localization in water pipeline systems based on WSNs," Comput. Networks, vol. 171, p. 107134, 2020. 